\title{
A Clinical Study of Patients with Acute Epiglottitis
}

\author{
Michihisa Kono ${ }^{1}$ Takashi Goto $^{1}$ Nobuyuki Bandoh ${ }^{1}$ Yasuaki Harabuchi ${ }^{2}$ \\ ${ }^{1}$ Department of Otolaryngology-Head and Neck Surgery, Hokuto \\ Hospital, Obihiro, Hokkaido, Japan \\ 2 Department of Otolaryngology-Head and Neck Surgery, Asahikawa \\ Medical University, Asahikawa, Hokkaido, Japan \\ Address for correspondence Nobuyuki Bandoh, MD, PhD, \\ Department of Otolaryngology-Head and Neck Surgery, Hokuto \\ Hospital, 080-0833 7-5 Kisen, Inada-cho, Obihiro, Hokkaido, Japan \\ (e-mail: bando@hokuto7.or.jp).
}

Int J Pract Otolaryngol 2018;1:e1-e5.

\begin{abstract}
Acute epiglottitis is an acute inflammation of the upper respiratory airway that rarely causes airway obstruction. A retrospective study was conducted on 115 patients with acute epiglottitis from April 2007 to December 2017 (65 males and 50 females; aged 1285 years old, median age of 45 years). When counting the number of patients according to the month, from April to September more than 10 patients were treated. Median duration from symptom onset to first visit was 3 days (1-14 days). Eight (7\%) of 115 patients had diabetes, and 16 (13.9\%) had epiglottic cyst. We divided all the patients into six groups by laryngeal findings according to the classification of Katori and Tsukuda. Number of patients classified as IA, IB, IIA, IIB, IIIA, and IIIB was 41 (35.7\%), 21 (18.3\%), 22 (19.1\%), 15 (13\%), $8(7 \%)$, and $8(7 \%)$, respectively. Median duration of hospitalization was 5 days (2-26 days). In the blood test on the first day of hospitalization, the number of white blood cells (WBC) ranged from 3,400 to $25,350 / \mu \mathrm{L}$ (median $10,350 / \mu \mathrm{L}$ ) and the C-reactive protein (CRP)

Keywords

- acute epiglottitis

- airway management

- laryngeal finding

- inflammatory reaction in blood test

- tracheotomy ranged from 0.01 to $23.3 \mathrm{mg} / \mathrm{dL}$ (median, $2.5 \mathrm{mg} / \mathrm{dL}$ ). The number of WBC and CRP at the fourth day after the hospitalization was significantly lower than those at the first day. Eight (7\%) patients required the airway management such as tracheotomy or cricothyroidotomy. Age, laryngeal finding (severe epiglottis swelling and arytenoid edema; Katori and Tsukuda's classification IIIB), and high inflammatory reaction in blood test (WBC $\geq 20,000 / \mu \mathrm{L}$ and $\mathrm{CRP} \geq 20 \mathrm{mg} / \mathrm{dL}$ ) were the factors that significantly correlated with the airway management.
\end{abstract}

\section{Introduction}

Acute epiglottitis is often observed in clinical practice in the field of otolaryngology; there is a possibility of rapid airway obstruction, which may be fatal, and therefore, this disease requires a prompt and appropriate intervention. Many patients are ameliorated by conservative treatment alone; thus, in many cases, it is difficult to determine the necessity and timing of airway management. Herein, we retrospectively analyzed inpatients with acute epiglottitis who were treated in our department.

\section{Materials and Methods}

The subjects were 115 inpatients with acute epiglottitis who were admitted to our department from April 2007 to
December 2017. In our department, patients who are diagnosed with acute epiglottitis are hospitalized on the same day, and a penicillin antibiotic ( $3 \mathrm{~g}$ of ampicillin/sulbactam twice a day), a steroid (100 mg of hydrocortisone succinate), an intravenous drip infusion, and a nebulizer are set as the basic course of treatment. In the present study, the sex, age, visit date, number of days from onset to consultation, presence or absence of diabetes, presence of an epiglottic cyst, laryngeal findings, and hospitalization duration were analyzed. In addition, a hematological examination (white blood cell count, C-reactive protein [CRP] level) was performed on admission and on hospital day 4, and the numerical values were compared. Acute epiglottitis was clinically diagnosed based on laryngeal findings. Regarding laryngeal findings, received January 9, 2018 accepted February 28, 2018
DOI https://doi.org/ $10.1055 / \mathrm{s}-0038-1660522$. eISSN 2569-1783.
Copyright (c) 2018 Georg Thieme Verlag License terms KG Stuttgart · New York

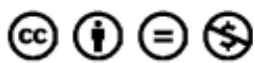


according to the classification proposed by Katori and Tsukuda, ${ }^{1}$ cases of mild epiglottic swelling in which the total length of the bilateral vocal cords could be observed were classified as I, cases of moderate epiglottic swelling in which the full length of the vocal cords could not be observed but at least half could be observed were classified as II, cases of severe epiglottic swelling in which less than half of the vocal cords could be observed were classified as III, cases with no arytenoid edema were classified as A, and cases with arytenoid edema were classified as B. Airway management was performed in each case at the discretion of the attending physician on the basis of laryngeal findings. Fisher's exact test and logistic regression analysis were used to compare the airway management group and the non-airway management group. The Wilcoxon signed-rank test was used for the comparison of hematological examination results.

\section{Results}

There were 65 cases of acute epiglottitis (56.5\%) in males and 50 cases $(43.4 \%)$ in females; it was somewhat more common in men, and the median age was 45 years (12-85 years) (-Fig. $\mathbf{1}$ ). When counting the number of patients according to the month, the number of patients from April to September exceeded 10, but in October to December, there were as few as 5 (-Fig. 2). The number of days from onset to consultation was 2 and 3 days, and the median was 3 days (1-4 days) ( - Fig. 3 ). Eight ( $7 \%$ ) of the 115 patients had diabetes and $16(13.9 \%)$ had epiglottic cysts. In laryngeal findings on admission, mild epiglottic swelling (I) was the most common (62 patients, 53.9\%), followed by moderate epiglottic swelling (II) (37 patients, 32.1\%), and severe epiglottic swelling (III) (16 patients, 14\%) (-Table 1). A total of 71 patients (61.7\%) had no edema of arytenoid (A) and 44 (38.3\%) had edema (B). The mean hospitalization duration was long ( 4 and 5 days), and the median value was 5 days (2-26 days) (-Fig. 4). The medians of the white blood cell count and CRP level on admission were $10,350 / \mu \mathrm{L}(3,400-25,350 / \mu \mathrm{L})$ and $2.5 \mathrm{mg} / \mathrm{dL}(0.01-23.3 \mathrm{mg} / \mathrm{dL})$, respectively. Hematological examinations performed on hospital day 4 revealed that the

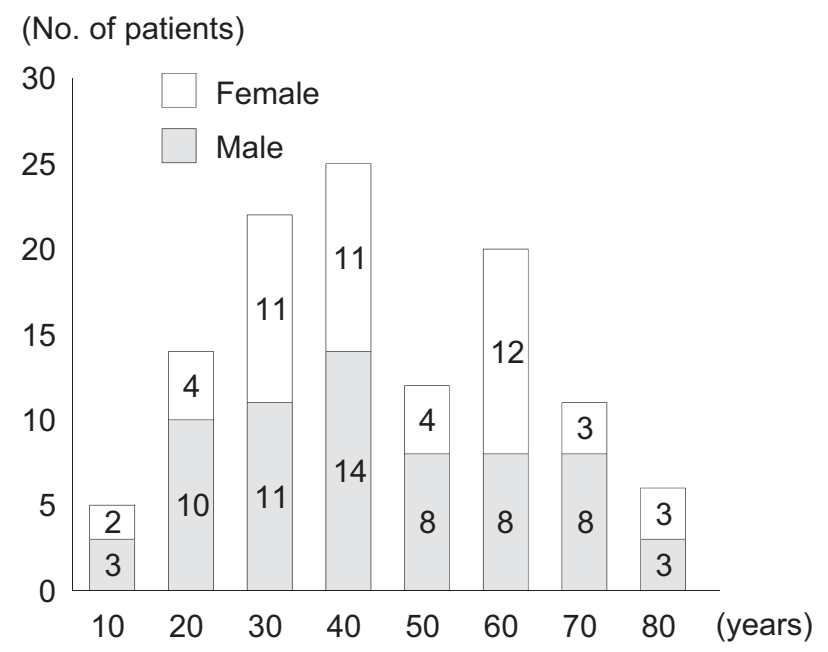

Fig. 1 Age and sex. Acute epiglottitis is somewhat more common in men, mostly in their 40 s.

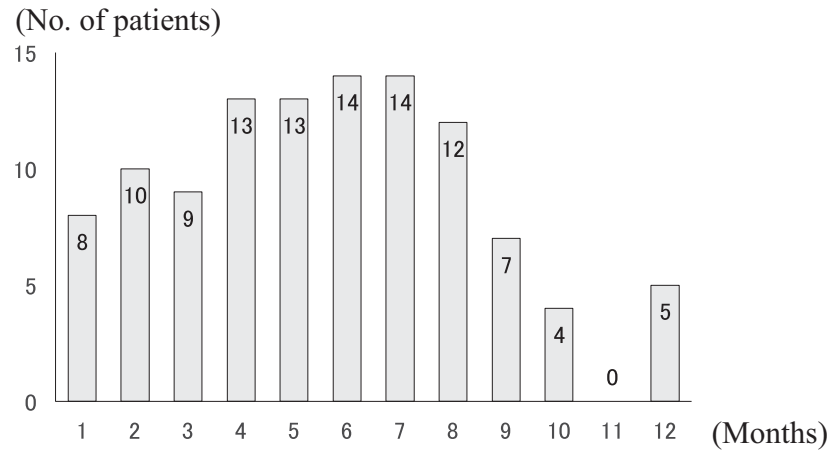

Fig. 2 Number of patients per month. We analyzed cases over 10 years from April 2007 to March 2017. From April to September, there were more than 10 patients with acute epiglottitis, but from October to December there were less than 5 patients with acute epiglottitis.

median white blood cell count was $6,480 / \mu \mathrm{L}(3,800-12,320 / \mu \mathrm{L})$ and the median CRP level was $1.2 \mathrm{mg} / \mathrm{dL}(0.01-20.3 \mathrm{mg} / \mathrm{dL})$, and there was a significant decrease compared with that on $\operatorname{admission}(p<0.01$ and $p<0.05 ;-$ Fig. 5 ). Airway management was performed in 8 out of 115 cases (7\%), of which 7 were males and 1 was female; the median age was 60 years (35-69 years). In laryngeal findings, IIIB of the classification of Katori and Tsukuda was noted in six of eight patients; in the hematological examination on admission, the white blood cell count and CRP level were $\geq 20,000 / \mu \mathrm{L}$ and $\geq 20 \mathrm{mg} / \mathrm{dL}$, respectively; the white blood cell count was $\geq 20,000 / \mu \mathrm{L}$ in two cases, whereas the CRP level was $<20 \mathrm{mg} / \mathrm{dL}$ in another two cases; the white blood cell count and CRP level were $<20,000 / \mu \mathrm{L}$ and $\geq 20 \mathrm{mg} / \mathrm{dL}$ in one case and $<20,000 / \mu \mathrm{L}$ and $<20 \mathrm{mg} / \mathrm{dL}$ in three cases, respectively. The method of airway management was as follows: tracheostomy under general anesthesia, five patients; tracheostomy under local anesthesia, one patient; tracheotomy after airway obstruction, one patient; and cricothyrotomy, one patient. The statistical analysis of factors related to the airway management group revealed an age of $>50$ years, laryngological findings of IIIB, a white blood cell count of $\geq 20,000 \mu \mathrm{L}$, and a CRP level of $\geq 20 \mathrm{mg} / \mathrm{dL}$ (-Table 2 ).

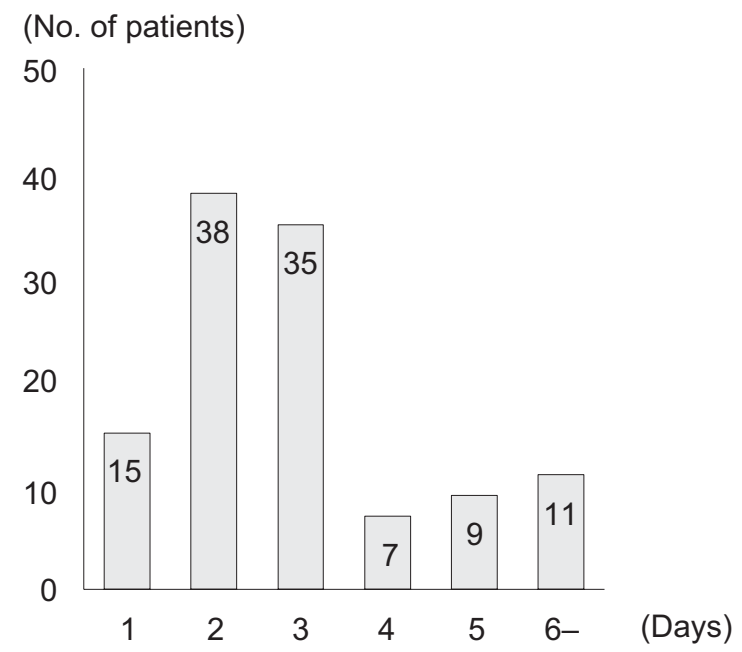

Fig. 3 Number of days from onset to consultation. The number of days from onset to consultation was 2 and 3 days. 
Table 1 Classification of laryngeal findings

\begin{tabular}{|l|l|l|l|l|l|}
\hline \multicolumn{2}{|c|}{} & \multicolumn{2}{|l|}{ Epiglottic swelling } & \multirow{2}{*}{ Total } \\
\cline { 3 - 6 } \multicolumn{2}{|c|}{} & Mild (I) & Moderate (II) & Severe (III) & \\
\hline $\begin{array}{l}\text { Arytenoid } \\
\text { Edema }\end{array}$ & None (A) & 41 patients (35.7\%) & 22 patients (19.1\%) & 8 patients (7\%) & 71 patients (61.7\%) \\
\cline { 2 - 7 } & Yes (B) & 21 patients (18.3\%) & 15 patients (13\%) & 8 patients (7\%) & 44 patients (38.3\%) \\
\hline \multicolumn{2}{|l|}{\begin{tabular}{l} 
Total \\
\hline
\end{tabular}}
\end{tabular}

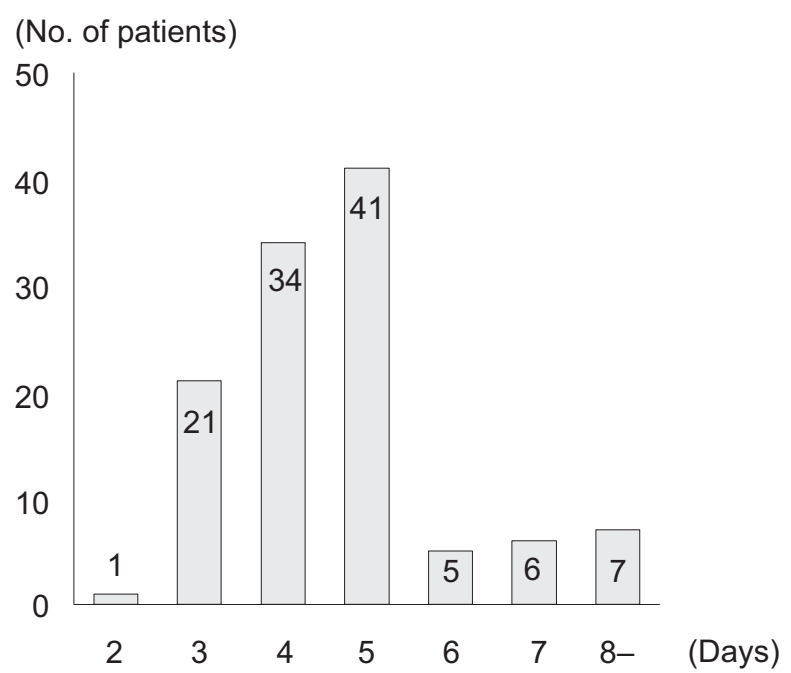

Fig. 4 Number of hospital days. Duration of hospitalization was 4 and 5 days.

\section{Discussion}

Acute epiglottitis is considered a childhood disease in Western countries, but it is seen in adults in Japan. ${ }^{2-9}$ The results of the present study are consistent with those of past reports with regard to the fact that median age was 45 years and most subjects were in their 30s to 60s. It has been reported that the onset of acute epiglottitis is somewhat more common during the summer season, ${ }^{10-12}$ but it has also been reported that there is no predilection in terms of time. $6,13,14$ In the present study, many cases of acute epiglottitis tended to occur from spring to summer. The most common number of days from onset to consultation is said to be 2 to 3 days, $, 3,11,15$ and in the present study, similar results (median of 3 days) were noted. In addition, five of eight cases of airway management had consultations within 2 days of onset. In patients requiring airway management, there are many reports that the number of days from onset to consultation is within 24 hours, ${ }^{1,5,6,8,15}$ and it has

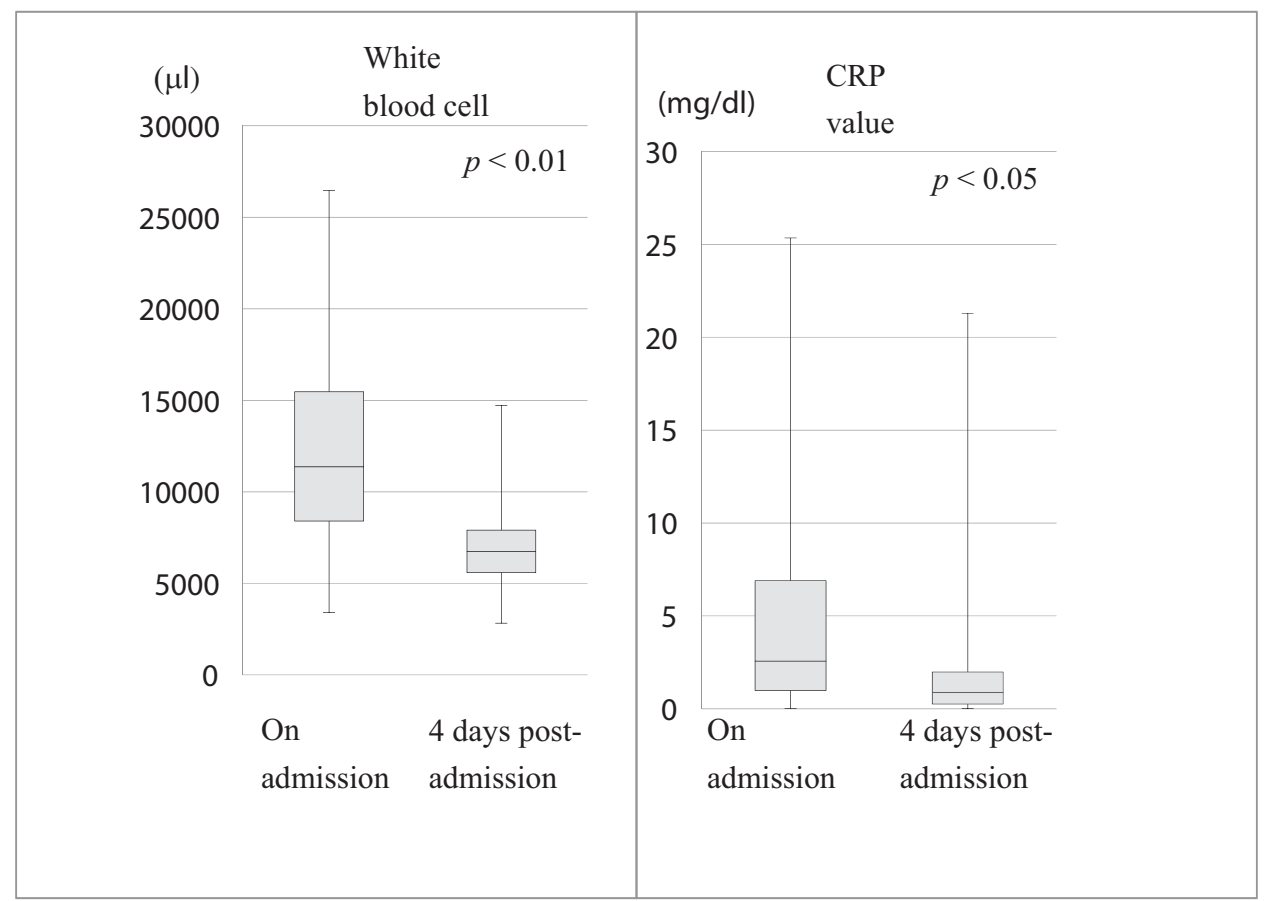

Fig. 5 The white blood cell count and C-reactive protein (CRP) level on admission and on hospital day 4. There was a significant decrease in the white blood cell count and CRP level on hospital day 4 when compared with that upon admission. 
Table 2 Relationship between airway management and each item

\begin{tabular}{|c|c|c|c|c|c|c|}
\hline \multicolumn{2}{|l|}{ Investigation items } & $\begin{array}{l}\text { Non-airway } \\
\text { management } \\
\text { group } \\
\text { (107 patients) }\end{array}$ & $\begin{array}{l}\text { Airway } \\
\text { management } \\
\text { group } \\
\text { (8 patients) }\end{array}$ & $p$-Value ${ }^{a}$ & $\begin{array}{l}\text { Odds } \\
\text { ratio }\end{array}$ & $\begin{array}{l}95 \% \\
\text { confidence } \\
\text { interval }\end{array}$ \\
\hline \multirow[t]{2}{*}{ Age (y) } & Less than 50 & 65 & 1 & \multirow[t]{2}{*}{0.01} & 1.0 & \multirow[t]{2}{*}{$1.3-91.2$} \\
\hline & 50 or older & 42 & 7 & & 10.8 & \\
\hline \multirow[t]{2}{*}{ Sex } & Female & 49 & 1 & \multirow[t]{2}{*}{0.14} & 1.0 & \multirow[t]{2}{*}{$0.7-49.7$} \\
\hline & Male & 58 & 7 & & 5.9 & \\
\hline \multirow{2}{*}{$\begin{array}{l}\text { Number of days from } \\
\text { onset to consultation }\end{array}$} & $3 \mathrm{~d}$ or later & 59 & 3 & \multirow[t]{2}{*}{0.47} & 1.0 & \multirow[t]{2}{*}{$0.47-9.0$} \\
\hline & Within $2 \mathrm{~d}$ & 48 & 5 & & 2 & \\
\hline \multirow[t]{2}{*}{ Diabetes } & None & 101 & 6 & \multirow[t]{2}{*}{0.09} & 1.0 & \multirow[t]{2}{*}{$0.9-33.9$} \\
\hline & Yes & 6 & 2 & & 5.6 & \\
\hline \multirow[t]{2}{*}{ Epiglottic cyst } & None & 92 & 7 & \multirow[t]{2}{*}{1} & 1.0 & \multirow[t]{2}{*}{$0.1-7.6$} \\
\hline & Yes & 15 & 1 & & 0.8 & \\
\hline \multirow[t]{2}{*}{ Laryngeal findings } & Other than IIIB & 101 & 2 & \multirow[t]{2}{*}{0.0001} & 1.0 & \multirow[t]{2}{*}{$18.1-1,269$} \\
\hline & IIIB & 2 & 6 & & 151 & \\
\hline \multirow{2}{*}{$\begin{array}{l}\text { White blood cell } \\
\text { count on admission }\end{array}$} & Less than $20,000 / \mu \mathrm{L}$ & 106 & 4 & \multirow[t]{2}{*}{0.0001} & 1.0 & \multirow[t]{2}{*}{$9.5-1,178$} \\
\hline & $20,000 / \mu \mathrm{L}$ or higher & 1 & 4 & & 106 & \\
\hline \multirow[t]{2}{*}{ CRP level on admission } & Less than $20 \mathrm{mg} / \mathrm{dL}$ & 106 & 5 & \multirow[t]{2}{*}{0.0001} & 1.0 & \multirow[t]{2}{*}{$5.6-726$} \\
\hline & $20 \mathrm{mg} / \mathrm{dL}$ or higher & 1 & 3 & & 63.6 & \\
\hline
\end{tabular}

Abbreviation: CRP, C-reactive protein.

${ }^{a}$ Calculated by Fisher's exact probability test.

been indicated that rapid progression is likely to lead to airway obstruction. ${ }^{5}$

The prevalence of diabetes in the present study was 7\%, which was lower than the proportion of people in Japan who were "highly suspected to have diabetes" $(12.1 \%)$ reported by the Ministry of Health, Labor and Welfare Ministry in 2016. It has been reported that the history of diabetes is related to aggravation rather than the onset of acute epiglottitis. ${ }^{1,11,16}$ In the present study, two of eight patients requiring airway management had diabetes and required emergency airway management after airway obstruction. Therefore, in patients with diabetes, it seems necessary to consider the potential of rapid progression and aggravation of acute epiglottitis. Epiglottic cysts were observed in 16 of 115 patients (13.9\%). In past reports, the frequency was indicated to be 7 to $14 \%, 2,4-7,11,15$ and epiglottic cysts appeared to cause acute epiglottitis. It has been reported that epiglottic cysts are correlated with the severity of acute epiglottitis, ${ }^{17}$ but it has also been reported that there is no correlation. ${ }^{2,4,5}$ In the present study, no relationship of epiglottic cyst with airway management was noted.

When the white blood cell count and CRP level on admission and on hospital day 4 were compared, both were significantly lower on hospital day 4 . This suggests that the condition of many patients improved with conservative treatment, and penicillin antibiotic and steroid administrations were efficacious in our department. In the present study, a white blood cell count of $\geq 20,000 / \mu \mathrm{L}$ and a CRP level of $\geq 20 \mathrm{mg} / \mathrm{dL}$ were identified as factors correlated with the airway management group. Because patients with high inflammatory response values are considered to be severe, it is considered to be one factor in the determination of airway management. As specific numerical values, a white blood cell count of $\geq 15,000-20,000 / \mu \mathrm{L}$ and a CRP level of $\geq 10-20 \mathrm{mg} / \mathrm{dL}$ have been reported as indicators of airway management. ${ }^{7,18-20}$ Furthermore, Kikuchi and Nishida ${ }^{18}$ reported that the mean white blood cell count in eight patients requiring tracheotomy was $20,625 / \mu \mathrm{L}$. However, acute epiglottitis requiring airway management is said to proceed rapidly, and there are many patients who visit in a short period of time from the onset; it has been indicated that the inflammatory response values do not increase depending on the timing of hematological examination. ${ }^{7}$

The severity classification of laryngeal findings in acute epiglottitis includes: the classification of Katori and Tsukuda, ${ }^{1}$ which separately classifies an epiglottic swelling and arytenoid edema; the classification of Uwa et $\mathrm{al}^{3}{ }^{3}$ which focuses on the swelling of the false cords in addition to the epiglottis and arytenoid edema; the classification of Kikuchi and Nishida, ${ }^{18}$ which classifies according to the presence or absence of swelling and dyspnea; and the classification of Friedman et $\mathrm{al}^{21}$ in which classifications involving only respiratory symptoms, etc., are shown. In the present study, the classification system of Katori and Tsukuda, which classifies laryngeal findings into an epiglottic swelling and arytenoid edema, was used. In the present study, 8 of the 115 patients presented the most severe cases of IIIB (7\%) and, of these, airway management was performed in 6 . 
In addition, eight patients requiring airway management presented with edema (B), and eight cases of IIIA without arytenoid edema did not require airway management, although epiglottic swelling was advanced. Katori and Tsukuda ${ }^{1}$ indicated that airway management should be considered in the case of IIIB, and it has been clarified that cases requiring airway secretion are closely related to edema, which is more prevalent than epiglottic swelling. ${ }^{6,9,15,22}$ Therefore, this classification, which separately classifies the epiglottic swelling and the edema of arytenoid, was considered to be useful.

The following have been reported as indications of airway management for acute epiglottitis: (1) orthopnea, (2) epiglottic swelling accompanied by severe arytenoid swelling, and (3) dyspnea within 24 hours of onset. ${ }^{22,23}$ Furthermore, it has been reported that (1) airway stenosis symptoms during the initial visit, (2) airway stenosis symptoms within 1 day from onset until receiving a medical examination at a medical institution, and (3) Katori and Tsukuda's classification III are the indications for airway management. ${ }^{5}$ Airway management was performed in 8 of 115 patients (7\%) in the present study. According to past reports, the rate at which airway management was implemented was 5.6 to $10.9 \%,{ }^{1-9,11}$ and similar results were obtained in the present study. In our department, the method of airway management is based on tracheostomy under general anesthesia after sharing laryngoscopic findings with the anesthesiologist. If it is determined that intubation is difficult, tracheotomy is performed under local anesthesia. Furthermore, in the case of airway management after airway obstruction, cricothyrotomy can be performed in a short time and is useful. Suzuki et $\mathrm{al}^{17}$ report that, as a result of data analysis of $\sim 6,000$ cases of acute epiglottitis, factors of necessity of airway management or aggravation, including fatal cases, were older males, high body mass index, past history of diabetes, epiglottic cyst, and comorbid pneumonia on admission. Regarding the necessity of airway management, in addition to these factors, it was considered important to determine and evaluate advanced epiglottic swelling, arytenoid edema, and high inflammatory reaction values from the results of the present study.

\section{Conclusion}

When examining 115 patients with acute epiglottis who were admitted to our department, it was somewhat more common in males aged 30 to 60 years and during April to September. Many cases were ameliorated by antibiotic and steroid administrations. Eight cases (7\%) required airway management. In acute epiglottitis, laryngeal findings (severe epiglottic swelling and arytenoid edema; Katori and Tsukuda's classification IIIB) and high inflammatory response (white blood cell count and CRP level) were identified as factors correlated with airway management.

Conflict of Interest

None declared.
Patient Consent

Informed consent for publication of clinical details was obtained from all patients.

\section{References}

1 Katori H, Tsukuda M. Acute epiglottitis: analysis of factors associated with airway intervention. J Laryngol Otol 2005;119(12): 967-972

2 Tanaka S, Kikuchi S, Ohata A, Tsutsumi T, Ohki M. A clinical study of 285 cases of acute epiglottitis [in Japanese]. Nippon Jibiinkoka Gakkai Kaiho 2015;118(11):1301-1308

3 Uwa N, Hatta C, Tsuji K, et al. Clinical study of 29 cases of acute epiglottitis [in Japanese]. Pract Otorhinolaryngol 2003;96(09): 811-817

4 Kametani R, Manaka K, Matsunaga E, et al. Clinical study of 93 cases of acute epiglottitis. J Japan Broncho Esophagol Soc 1998; 49:436-441

5 Murata T, Muroi M, Furuya N. Acute epiglottitis: analysis of factors associated with tracheostomy. Pract Otorhinolaryngol 2010;103: 833-838

6 Ishida E, Katori Y, Watanabe K, et al. A clinical study of 71 cases of acute epiglottitis [in Japanese]. Nippon Jibiinkoka Gakkai Kaiho 2007;110(07):513-519

7 Koizumi H, Ohbuchi T, Nagatani G, et al. A clinical study of 64 cases of acute epiglottitis. Pract Otorhinolaryngol 2012;105: 1079-1083

8 Kimura S, Tsubuku T, Matsumura M, et al. A clinical study of 54 cases of acute epiglottitis. J Japan Soc Head Neck Surg 2015;25:351-356

9 Hasegawa K, Ichihara S, Nishikawa S, et al. Clinical study of 91 cases of acute epiglottitis. J Japan Broncho Esophagol Soc 2013; 64:175-181

10 Sugio Y, Kukita N, Fujitani S, et al. Clinical analysis of acute epiglottitis. J Japan Soc Infect Dis Otolaryngol 2000;18:33-36

11 Takagi H, Horiguchi S. Treatment of acute epiglottitis: epidemiology of acute epiglottitis. ENTONI 2004;08:1-6

12 Yamagiwa M. Acute epiglottitis. Otolaryngology 1987;59(01): 59-63

13 Katori H, Tsukuda M, Taguchi T, et al. Clinical investigation of acute epiglottitis. Otolaryngol Head Neck Surg 2004;76:721-724

14 Matsumoto S, Saiki T, Sakaki M, et al. Clinical study of 122 cases of acute epiglottitis with hospital treatment. Pract Otorhinolaryngol 2009;102:857-864

15 Iida M, Hesaka H, Matsui M, et al. Clinical investigation of 170 cases of acute epiglottitis. Otorhinolaryngology 1999;42:374-379

16 Taniyama T, Sugiyama T, Araki M, et al. A study of 68 cases of acute epiglottitis. J Japan Broncho Esophagol Soc 2014;65:221-225

17 Suzuki S, Yasunaga H, Matsui H, Fushimi K, Yamasoba T. Factors associated with severe epiglottitis in adults: analysis of a Japanese inpatient database. Laryngoscope 2015;125(09):2072-2078

18 Kikuchi M, Nishida Y. Treatment of acute epiglottis: Staging of acute epiglottitis. ENTONI 2004;08:20-24

19 Yoshifuku K, Ohhori J, Miyashita K, et al. Usefulness of scarification for patients with adult acute epiglottitis. J Japan Soc Infect Dis Otolaryngol 2013;31:125-128

20 Miyazawa T, Murata H, Shimode Y, et al. Timing for emergent airway preservention of acute epiglottitis in adults. J Japan Soc Infect Dis Otolaryngol 2008;26:125-129

21 Friedman M, Toriumi DM, Grybauskas V, Applebaum EL. A plea for uniformity in the staging and management of adult epiglottitis. Ear Nose Throat J 1988;67(12):873-874, 876-877, 880

22 Hashimoto D, Yao K, Nishiyama K, et al. A clinical study of 237 cases of acute epiglottitis. J Japan Broncho Esophagol Soc 2004; 55:245-252

23 Hayashi T. Acute epiglottitis: clinical judgment for airway intervention. Pract Otorhinolaryngol 2010;103:786-787 